\title{
The Value of Pollinators and Pollinator Habitat to Rangelands: Connections Among Pollinators, Insects, Plant Communities, Fish, and Wildife
}

\section{By Wendell Gilgert and Mace Vaughan}

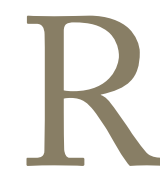

ecall one of those perfect late spring days you have spent out on the rangelands where you live or work; the wind calm, an azure sky with sparse heat, robust green grass and colorful wildflowers dotting the landscape, and a low background buzz and hum of insects accentuated by the singing of territorial songbirds. It doesn't matter if your recollection is related to shortgrass prairie; pinyon-juniper, sage-steppe, oak, or short-leafed pine savannah; or desert-shrub rangelands, the producers of the buzz and hum you heard are very likely related, essential, and largely ignored denizens of rangeland communities: bees and other native pollinators.

Native pollinating bees are a vital component of the biologically diverse plant and animal community which is critical to healthy, ecologically functional range landscapes. There are more than 20,000 species of bees world-wide. They exist on every continent except Antarctica. Over 4,000 species are known in the United States, most of which are solitary ground-nesting bees. Not only do they provide the essential environmental amenity of pollination, but by providing pollination, they allow for the existence of a host of other environmental services, including the continuation of multiple trophic levels of the food web. Many Lepidoptera (moths and butterflies), wasps, flies, beetles, and other insects also are pollinators, but they are not nearly as efficient as bees in moving pollen from flower to flower.

Managing rangelands to enhance life requisites for native pollinators likely will require adjusting current practices. Because of the lack of recognition of the ecological value of native pollinators it might not be a priority for us to do so. Because ecological services commonly are viewed through an anthropomorphic lens, and where the value assigned depends on the experience and knowledge of the individual, it is important to carefully define the service and what the service provides. Yet, as Aldo Leopold wrote in $1935,{ }^{1}$ we do not often understand the complexity of these services.

The long and short of the matter is that all land-use technologies - agriculture, forestry, watersheds, erosion, game and range management-are encountering unexpected and baffling obstacles which show clearly that despite the superficial advances in technique, we do not yet understand and cannot yet control the long-term interrelationships of animals, plants, and mother earth [emphasis added].

For example, from a native bee perspective, prairie dogs provide bare ground for solitary ground-nesting bees,

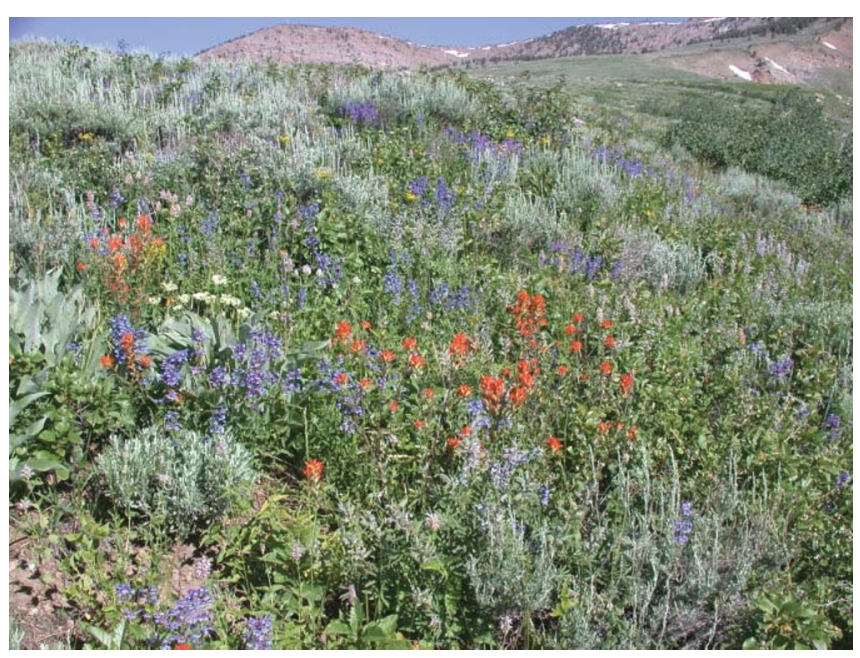

Rangelands can be managed to supply diverse and abundant flowering plants. Photo by Gary Back. 
burrows for bumble bee nests, and disturbance to provide early successional habitat to support abundant forbs and legumes, all essential habitat elements. And although prairie dogs also provide soil aeration, reduced soil compaction, and added fertility to the soil from dung, urine, and belowground stored vegetation, it is safe to say that many landowners do not recognize or appreciate the potential pollinator benefits derived from them; rather they see varmints that leave a landscape covered in burrows and often bare of vegetation.

\section{What Is Good Pollinator Habitat?}

The most important element of high-quality-pollinator habitat is an abundant and diverse array of flowering plants. These include a wide variety of annual and perennial forbs and legumes, shrubs, vines, and trees that initiate flowering early in the spring and continue late into the fall. Willows (Salix spp.) provide some of the earliest flowers in most of North America, a time when ground-nesting miner bees (Andrena spp.) and queen bumble bees (Bombus spp.) are first emerging. Goldenrod (Solidago spp.) and asters continue to flower after the first frosts in autumn and allow new bumble bee queens to store body fat for their winter hibernation. Willows, goldenrod, and all of the flowers that bloom in between, provide the pollen and nectar resources needed by the wide variety of bee species that emerge throughout the growing seasons.

Diverse plant communities provide more than just food to our bees, however. Beetle burrows in trees and shrubs, or the pithy centers of some stems, provide natural nesting sites for about $30 \%$ of our native bees. These bees are solitary species that stack their brood cells, one next to the other, inside these tunnels.

The remaining (70\%) native bees nest in the ground. These ground-nesting species need to have areas-large or small—of bare soils, usually with full exposure to the

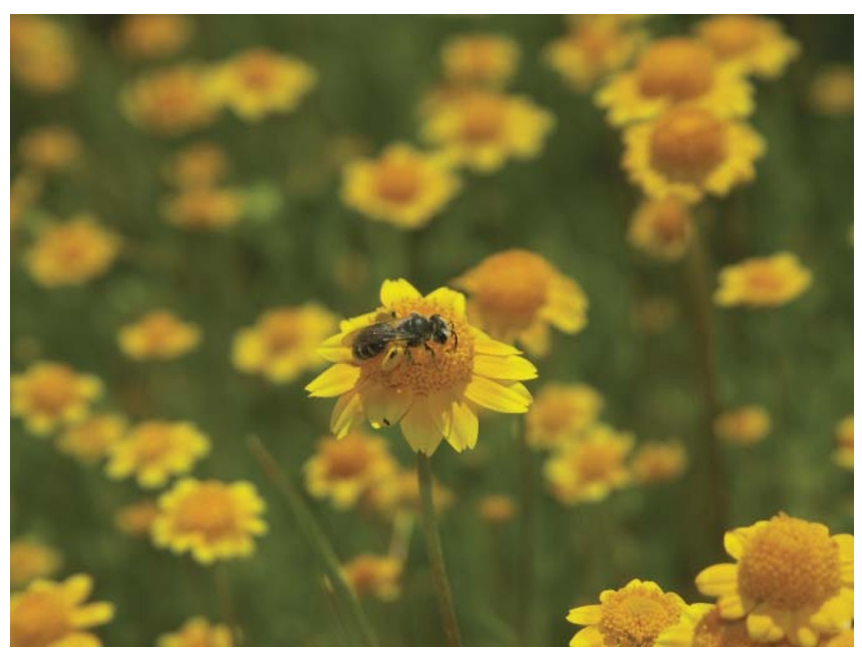

A ground-nesting miner bee (genus Andrena) collecting pollen and nectar from goldfields (genus Lasthenia) at a vernal pool in California's Central Valley (Yolo County). Photo by Mace Vaughan, Xerces Society. sun, into which the females can excavate their nests. In many cases, the surface entrances to these nests look like collections of ant mounds.

Many bumble bee species also nest under or on the ground, but instead of digging narrow underground tunnels, they utilize existing cavities, such as those left behind by burrowing mammals. Although their nests usually occupy underground burrows, they also take advantage of thick layers of grass or other thatch on the surface where mice or voles construct nests that provide the desired insulation to rear a new generation of offspring.

\section{What Do These Habitat Components Mean for Insect Diversity?}

A diversity and abundance of plants that produce nectar and pollen used by insects, combined with a variety of standing or downed dead wood, bare ground, and overgrown vegetation, are the hallmarks of rich heterogeneous pollinator habitat. This habitat should be considered across political and land management boundaries, where pollinator-in this case, native bees-life history requisites are ideally situated within the typical bee flight range. Small bees fly 200 meters or less, but larger species, such as bumble bees, easily can cover more than $2 \mathrm{~km}$ in their search for pollen and nectar. When viewed this way, the resources of the sunny meadow take their place alongside those of the stream bank and the forest edge, meeting the diverse needs of pollinators, but also the habitat needs of a wide variety of other insects and invertebrates.

We know that diverse plant communities are important for butterfly and moth (Lepidoptera) diversity. ${ }^{2}$ The caterpillars of Lepidoptera species have specific host plant needs. In some cases, a moth or butterfly has a single genus or even species of plant upon which it feeds. Others are much more liberal in their tastes, but in either case, managing for diverse plant communities for native bees will greatly assist in increasing the abundance of Lepidoptera.

Similarly, diverse rangeland plant communities support diverse assemblages of grasshoppers, crickets, and other orthopterans, with the interesting side effect of mitigating or preventing outbreaks. Of the 400 or so grasshopper species in the United States, only about a dozen actually pose a risk of outbreak. ${ }^{3}$ These species, and their nonpestiferous cousins, eat a wide variety of plant species, and often are in competition for resources. As a result, diverse plant communities help support a diversity of grasshoppers that compete for limited resources and help prevent outbreaks of economically important species. Likewise, diverse rangeland plant communities provide a consistent supply of floral nectar sources that are utilized by insect predators and parasites that feed upon both nonpest and pest grasshopper species. Some species of blister beetles (Meloidae) and bee flies (Bombyliidae) are grasshopper egg predators, and several species of solitary wasps (Sphecidae) and parasitic flies (e.g., Tachinidae) attack grasshopper nymphs and adults. 
Adults of these insects feed on nectar, and this biological control further helps to prevent outbreaks. ${ }^{4}$

\section{What Does Insect Diversity Mean for Fish and Wildlife?}

Although native bee pollinators are the main focus of this paper, it is important to recognize the array of invertebrate interactions with fish and wildlife in rangelands. The relationships between heterogeneous plant communities and insects (and other invertebrates) are reflected in a wide variety of other species, from ants to spiders, and have significant implications for fish and wildlife communities. For example, several studies in Japan, New Zealand, North America, and South America have demonstrated that diverse terrestrial plant communities along riparian areas result in the production of abundant insects and spiders that fall or are wind-blown into streams and become critical food resources for fish. ${ }^{5}$

In a recent Rocky Mountain (Wyoming) study, researchers examined trout response to two types of livestock grazing treatments. In one set of treatments, ranchers used high-density, short-duration grazing (HDSD) that closely managed the season of use, the time cattle were allowed to graze in the riparian zone, and the intensity (number) of domestic cattle. The HDSD treatments were compared to season-long continuous grazing where the cattle were turned into large pastures (that included the riparian zones) at the beginning of the season and gathered at the end.

The researchers discovered that the use of high-density, short-duration grazing in the study area riparian zones resulted in an average 2.3-fold increase in the amount of terrestrial invertebrate biomass falling in streams. ${ }^{6}$ Willow (Salix spp.), red-osier dogwood (Cornus sericea), snowberry (Symphoricarpos albus), and currant (Ribes spp.), as well as Canada goldenrod (Solidago canadensis) and yellow sweet clover (Melilotus officinalis), all were more prolific in riparian areas managed under the prescriptive grazing utilized by the ranchers in the study area. These plants provide critical pollen and nectar resources required by pollinators. Additional benefits documented in the study were that areas with HDSD grazing areas had three times more aboveground riparian biomass, nearly twice the overhead cover, and more than twice the biomass of trout. Using prescribed grazing management, where livestock herbivory results in the availability of greater aboveground riparian biomass and greater overhanging riparian vegetation cover, can accrue tremendous benefits to pollinators, fish communities and riparian wildlife habitat.

Like the aquatic trout resource, most gallinaceous bird chicks (grouse, quail, and turkey) rely on insects as a source of protein ${ }^{7}$ and, overall, $61 \%$ of the bird species known to breed in the United States are primarily insectivorous and another $25 \%$ are at least partially insectivorous. ${ }^{8}$ One study of sage grouse on sage-steppe rangelands found that diverse plant communities were important for diverse Lepidopteran communities, which subsequently were a critical food

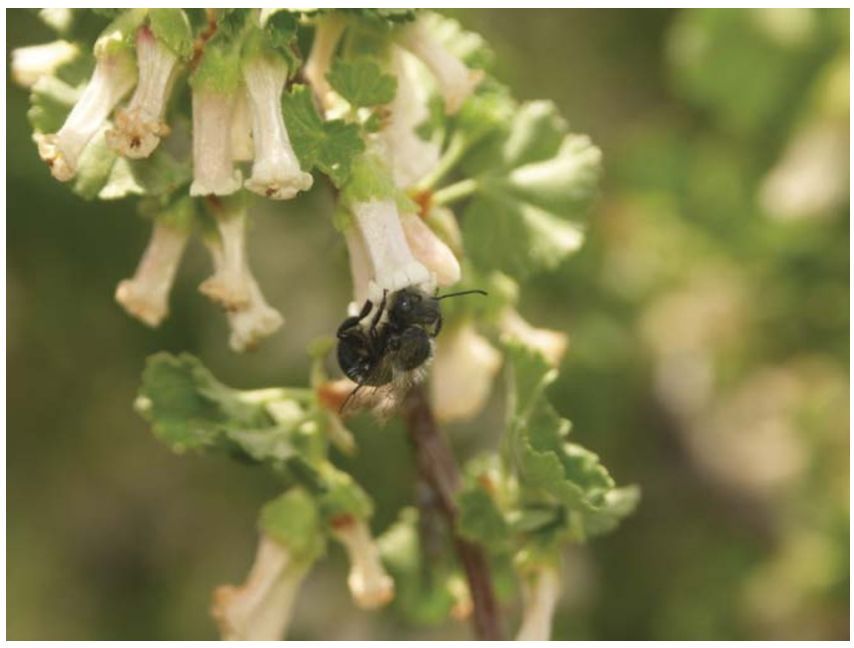

Leaf-cutter bee (genus Osmia) visiting wax currant flower (Ribes cereum) in eastern Oregon (Lake County). Photo by Mace Vaughan, the Xerces Society.

source for sage grouse chicks. ${ }^{9}$ Sage grouse in these forbrich habitats had significantly higher reproduction and chick survival. ${ }^{\mathrm{i}}$

Similar results have been found in studies looking at the relationship between interseeding forbs into rangeland habitats and the reproduction of Lesser Prairie Chicken (Tympanuchus pallidicinctus), Bobwhite Quail (Colinus virginianus), Ring-Neck Pheasant (Phasianus colchicus), and other gallinaceous game birds. In locations where local populations of these birds are holding steady or experiencing upward population trends, it is apparent that land managers are using practices that maintain vegetation heterogeneity, including early successional vegetation, as a key component of the landscape vegetation mosaic. Management practices, such as fire and grazing, that mimic natural disturbance regimes at an appropriate scale (see article by Black et al., this issue) can be important to implement in order to maintain those diverse landscape conditions. In short, good pollinator habitat is good for game birds. The same is certainly true of songbirds, most of which are insectivorous, and which consume insects found in diverse communities of trees, shrubs, vines, and herbaceous plants.

The connection between pollinators and birds goes beyond their reliance on insectivory. Not only do birds use insects and invertebrates to meet their dietary needs, but they also use seeds that are the result of insect pollination. Once more, plant diversity and abundant forbs have their own direct connections to bird populations. Bee-pollinated fruits and seeds also are the major food source for a wide variety

\footnotetext{
Note: The lack of availability of sufficient forbs in the herbaceous understory of sagebrush (Artemisia spp.) was identified as one of the threats to the long-term population viability of the Greater Sage Grouse (Centrocercus urophasianus) by the United State Fish and Wildlife Service In their 12-Month Findings for Petitions to List the Greater Sage Grouse as Threatened or Endangered in March 2010.
} 


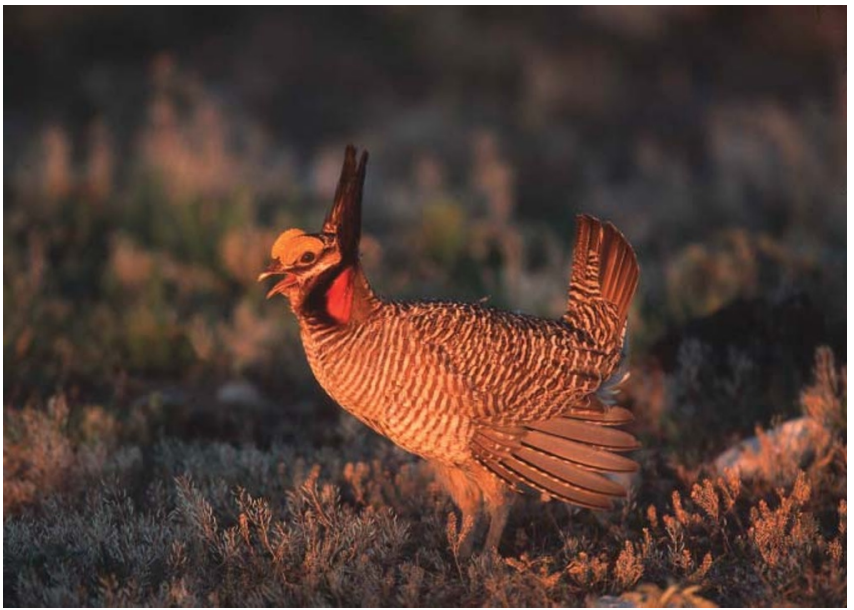

Lesser Prairie Chicken. Photo by Gary Kramer.

of other species, such as goldfinches, titmice, sparrows, and thrushes.

These same fruits and seeds are a critical resource for small and large mammals. Species as varied as voles (Microtus spp.) and grizzly bear (Ursus horribilis) rely upon seeds and berries. Raccoons (Procyon lotor), striped skunks (Mephitis mephitis), fox (Vulpes spp.), and coyotes (Canis latrans), also are known to gorge regularly on berries and seeds that are seasonally abundant.

Although grass production is the primary concern of ranchers producing cattle, the grasses, forbs and shrubs in complex rangeland environments also are the primary nutrition source for communities of large native ungulates. Both grazers and browsers also experience additional dietary benefit if rangelands are managed with increased dicotyledonous floristic resources. For example, $50-75 \%$ of mule deer (Odocoileus hemionus) diet consists of woody shrubs and forbs, that include bitterbrush (Purshia tridentata), mountain mahogany (Cercocarpus spp.), rabbitbrushes (Chysothamnus spp.), and various species of Ceanothus, most of which rely on native bees for pollination. Similarly, pronghorn antelope (Antilocapra americana) preferentially select shrubs and forbs, and consume grass for less than 5\% of their diet.

Range management that contributes to a heterogeneous landscape is accomplished by judicious and appropriate utilization of such common rangeland conservation practices as range seeding, prescribed burning, brush management, and rangeland mechanical treatment where the integration of a more diverse array of flowering shrubs, forbs and legumes can support diverse fish and wildlife populations that are compatible with cattle and sheep operations, as well as pollinators.

\section{Managing for Pollinators: A Useful Framework for Managing for Wildlife Biodiversity}

Because of the multiple connections between pollinator habitat and the diversity of wildlife and plant communities, pollinators provide a very useful framework for managing

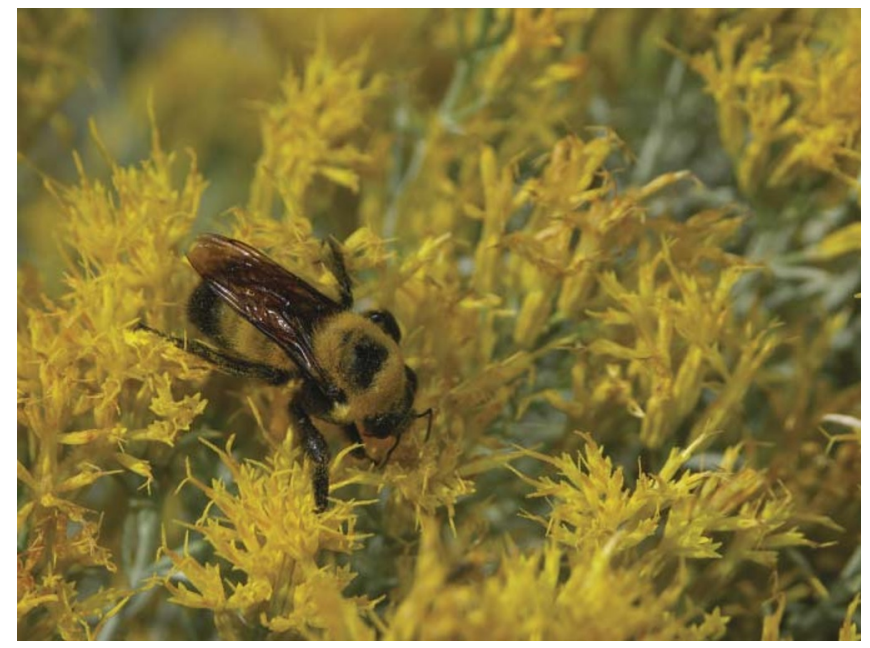

Bumble bee (genus Bombus) foraging for pollen and nectar on rabbitbrush (genus Chrysothamnus) in eastern Oregon (Lake County). Photo by Mace Vaughan, the Xerces Society.

habitat for biodiversity. Specific recommendations on how to manage large areas of rangeland habitat are given in the article by Black et al. (this issue). However, it is worth emphasizing a handful of core concepts we believe are particularly important.

The overarching objective of good pollinator habitat management and, by extension, high quality fish and wildlife habitat management, is to maintain rangelands with a high level of heterogeneity, which for some rangeland types means a predominance of early successional habitat. Depending on the type of rangeland, this can mean that managed disturbance can be a critically important management consideration. In many rangeland systems, such as grassland prairies, chaparral, and oak savannahs, grazing and fire are essential elements of this disturbance, but must be managed at a scale and intensity that allows forbs and legumes to be abundant, while simultaneously allowing for large areas of rangeland to serve as refugia from intense disturbance.

A contemporary example of landscape heterogeneity as a management goal can be found in the patch-burn grazing systems used at Homestead Ranch in the Flint Hills of Kansas. There, rancher Jane Koger carefully times the scale and intensity of grazing, and burns approximately one-third of each pasture each spring, to reintroduce and mimic historical disturbance on the land. The scale of management is such that large areas of the ranch are not disturbed in any one year, providing refuge areas from which pollinators can recolonize newly disturbed sites. As a result, the ranch supports abundant forbs, pollinators, and other wildlife (J. Koger and M. Weigelt, personal communication, July 2008).

We offer a different example in the Coast Range foothill rangelands adjacent to northern California's Central Valley where the Xerces Society is working with the USDA Natural Resources Conservation Service (NRCS), the local Resource 
Conservation District, and a local rancher to replant diverse forbs on his land. The goal of this rangeland project is to create an oasis of pollinator habitat in the midst of a working ranch. This is part of a nationwide effort by the NRCS and the Xerces Society to create pollinator habitats on farms and ranches.

At the Coast Range foothills site, a diverse mix of native forbs and nonnative forage legumes was seeded. The rancher is working to carefully manage grazing on the site to manage yellow star thistle and help the forbs and legumes become well-established. The producer grazed his cattle on the site at a high intensity for a short duration on several"occasions. The early outcome is that the grasses are not allowed to dominate the site to the exclusion of forbs and legumes, and invasive yellow star thistle is not allowed to flower; thus it is removed from the site over time. As a result, the forbs are becoming well-established. The producer recognizes that managing for diverse floristic resources is compatible with highly productive ranch management.

\section{Conclusions}

In his seminal work "Game Management," naturalist Aldo Leopold identified "the axe, the match, the cow, and the plow," as critical tools for game management. ${ }^{1}$ His recognition and endorsement of the use of appropriate management tools to mimic natural disturbance actions have stood the test of time and continue to be cornerstones of wildlife management. Those disturbances serve as the foundation for sustainable rangeland management as well. It is not a coincidence that using disturbance to create heterogeneous landscapes in support of sustainable, healthy rangelands also supports some of the highest quality pollinator habitats.

In the case of pollinators and other invertebrate biodiversity, however, it is important to reconsider the scale of use of the management tools Leopold outlined. Although grazing and fire once occurred at grand scales of thousands, even tens or hundreds of thousands of acres at a time, the

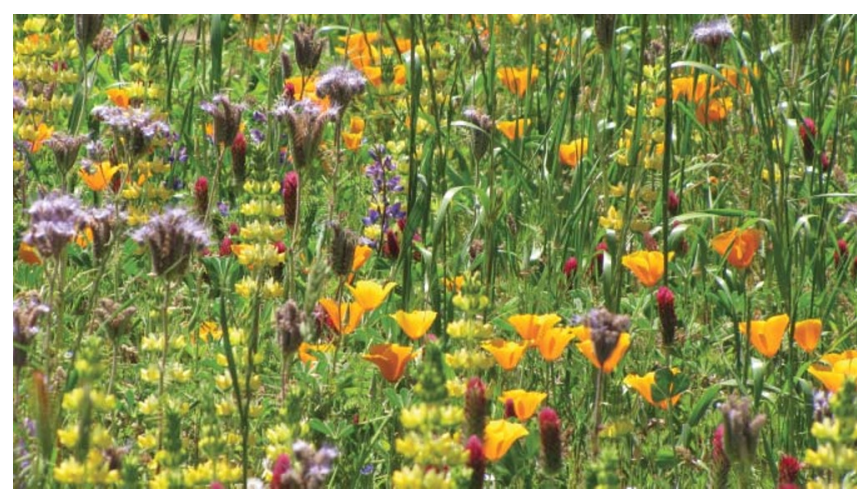

Diverse spring-flowering native and nonnative forage plants planted for pollinators on rangeland restoration site in the Coast Range foothills of northern California's Central Valley. Plant species in bloom in the late spring include phacelia, lupine, California poppy (Eschscholzia californica), and crimson clover. Photo by Claudia Street, Glen County Resource Conservation District. patchwork of private lands and high quality habitat (often small remnants) mean that management has to take into account sources of recolonization for pollinators and wildlife alike. The result is that managed disturbance should occur on a third or less of the overall habitat in any one year.

For this kind of management to take hold broadly requires either a commitment on the part of public land managers to target biodiversity (pollinator biodiversity more specifically) as a management goal, or private landowners to see evidence that such practices have long-term benefits in terms of profits or rangeland sustainability.

In the former case, the US Bureau of Land Management (BLM) and the US Forest Service (USFS) increasingly are interested in maintaining biodiversity on the rangelands they manage. Much BLM and USFS attention, for example, over the past year has focused on Greater Sage Grouse (C. urophasianus). It is widely recognized, however, that to best support the conservation of this species it is necessary to target management for forb and legume diversity. Similarly, the USFS and the Xerces Society have a growing interest in the conservation of the monarch butterfly. Efforts are underway to map habitat for this species on public lands, and increase the availability of milkweed (Asclepius spp.), its larval host plant, and additional nectar sources for adults.

At the same time, private landowners and ranchers are increasingly interested in conservation practices that support wildlife (and pollinators), so long as they are compatible with existing management goals, and technical support is available to support implementation. The NRCS and Xerces Society are working across the country with these landowners and managers to provide financial and technical resources to increase the use of practices that benefit pollinators.

Pollinator conservation, at its core, requires specific attention be paid to plant diversity, both in species composition and structure, a mix of disturbed and undisturbed habitats, and appropriate scale of management. These core management considerations provide a very useful framework for

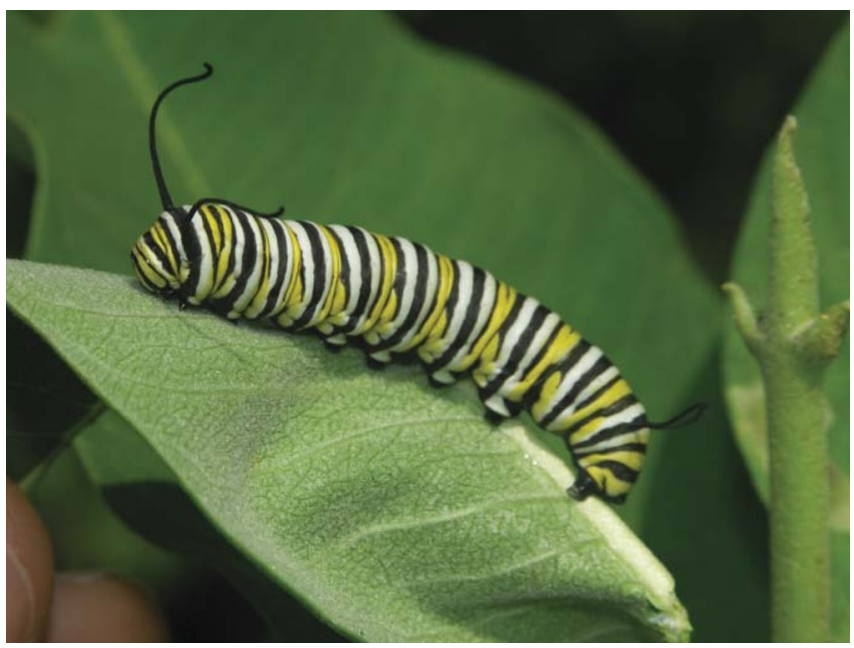

A monarch (Danaus plexippus) caterpillar feeding on milkweed (Asclepius sp.). Photo by Mace Vaughan, the Xerces Society. 
maintaining habitat that supports not just pollinators, but other invertebrates, fish, and wildlife. As a result, managing rangeland for pollinators provides a useful framework for overall biodiversity conservation, restoration, and management for public and private land managers alike.

\section{References}

1. Leopold, A. 1933. Game management. New York, NY, USA: Charles Scribner's Sons. 459 p.

2. Reis, L., D. M. Debinski, and M. L. Weiland. 2002. Conservation value of roadside prairie restoration to butterfly communities. Conservation Biology 15(2):401-411.

3. McAdoo, K., L. T. Vermeire, and W. C. Gilgert. 2004. The other grazers. Rangelands 26(3):30-37.

4. Branson, D. H., A. Joern, and G. A. Sword. 2006. Sustainable management of insect herbivores in grassland ecosystems: New perspectives in grasshopper control. BioScience 56(9):743-755.

5. Baxter, C. V., K. D. Fausch, and W. C. Saunders. 2005. Tangled webs: reciprocal flows of invertebrate prey link streams and riparian zones. Freshwater Biology 50:201-220.
6. Saunders, W. C., And K. D. Fausch. 2007. Improved grazing management increases terrestrial invertebrate inputs that feed trout in Wyoming rangeland streams. Transactions of the American Fisheries Society 136:1216-1230.

7. Liukkonen, A. T. 2001. Nutritional and genetic adaptation of galliform birds: implications for hand-rearing and restocking [PhD dissertation]. Oulu, Finland: University of Oulu. 73 p.

8. Losey, J. E., and D. M. Vaughan. 2006. The economic value of ecological services provided by insects. BioScience 569(4):311-323.

9. GregG, M. A. 2006. Greater sage-grouse reproductive ecology: linkages among habitat resources, maternal nutrition, and chick survival [PhD dissertation]. Corvallis, OR, USA: Oregon State University. 201 p.

Authors are West Region Wildlife Biologist, USDA-Natural Resources Conservation Service, West National Technology Support Center, Portland, OR 97232, USA, wendell.gilgert@ por.usda.gov (Gilgert); Pollinator Program Director, Xerces Society for Invertebrate Conservation, Portland, OR 97215, USA (Vaughan). 